\title{
Exploring the Theme of Self-Actualization in Maya Angelou's Poetry
}

\author{
Juan $\mathrm{Du}^{1}$ \\ ${ }^{1}$ School of Foreign Languages, Inner Mongolia University for the Nationalities, China \\ Correspondence: Juan Du, School of Foreign Languages, Inner Mongolia University for the Nationalities, \\ Tongliao City, Inner Mongolia, China. Tel: 86-137-2205-2772. E-mail: dujuan199507@163.com
}

Received: April 8, 2014 Accepted: June 24, 2014 Online Published: August 29, 2014

doi:10.5539/ells.v4n3p65 URL: http://dx.doi.org/10.5539/ells.v4n3p65

\begin{abstract}
Maya Angelou (1928-2014), an African American memoirist and poet, is best known for her autobiographic novel I Know Why the Caged Bird Sings and her long poem "On the Pulse of Morning" which she was invited to read at the inauguration of President Bill Clinton in 1993. As a contemporary black female writer, she distinguishes herself by infusing her art with consistent cultural consciousness, personal and cultural experience. Her poetry reveals themes of survival, development and self-discovery of African Americans. Knowing the destructive effects the hegemonic culture-White Anglo-Saxon Protestant (WASP) culture has exerted on African Americans, Angelou deeply feels the need to undermine the binary opposition of the dominant and subaltern cultures and reconstruct the cultural order. Therefore, the aim of this paper is to explore the theme of self-actualization of African Americans in her poetry. By redefining blackness and eulogizing the self-accepted black people, Angelou encourages African Americans to inherit their African cultural heritage and affirm their black identity. It concludes that her work manages to awaken African American's self-consciousness by encouraging them to preserve and celebrate their black culture.
\end{abstract}

Keywords: African American, poetry, cultural identity, resurrection, self

\section{Introduction}

Despite her popular and critical acclaim garnered by her autobiographies, Maya Angelou's poetry has been understudied, even after her recitation of "On the Pulse of Morning" in 1993 (DeGout, 2009, p.122). However, many of Angelou's readers still identify her as a poet first and an autobiographer second (Lupton, 1998, p.17). Reviewer Elsie B. Washington (2002) has called her "the black woman's poet laureate", and has called Angelou's poetry "the anthems of African Americans" (p.56). In spite of the negative and positive reviews, as an African American memoirist and poet, Maya Angelou distinguishes herself by infusing her art with consistent cultural consciousness. Following in the tradition like Hughes who creates a new African American identity, a proud sense of self in his poetry, Angelou speaks out the survival, development, and actualization of African American people confronted by the Anglo-American cultural hegemony with the best of words she can summon.

In this paper, the author proposes to analyze Maya Angelou's poetry with particular emphasis on the theme of self-actualization permeating her poetry. It can be explored in two respective aspects. First, she exposes African Americans' cultural identity issues by depicting their lives and experience. After being taken to America by slave traders, the Africans were forced to separate from their mother culture and identify with the new culture. As a result, their cultural identity was threatened and their self was distorted. With the emancipation of black slaves, African Americans were gradually entitled to civil rights. Nevertheless, African Americans were still driven out of the mainstream society with their own culture marginalized. Second, with a view to recover African Americans' self-consciousness, Angelou stresses the importance of affirming African American identity. In her poetry, she passionately depicts the New African Americans; images of self-actualized African Americans and the "black" metaphor work together to redefine African American culture. In the multicultural society, Angelou explores the self-consciousness of African Americans, identifies her people with the unique African American culture, and keeps alive ethnic culture.

\section{African Americans' Obscure Cultural Identity}

Guerin (2004) asserts that African American writing displays "an ambivalent consciousness arising from bicultural identity" (p.256). In Angelou's poetry, she gives objective description of her people's cultural status. Her works always reflect the truth that within the white dominating cultural milieu, African Americans are 
frequently prevented from being fully accepted by mainstream culture. Struggling between choosing Anglo-Saxon culture and keeping African culture, African Americans inevitably encounter obscure cultural identities.

\section{1 "Caged Bird"}

In Angelou's poem "Africa", she presents a rather vivid picture of the colonizing process of Africa. In the poem, the colonized Africa is seen as a mother robbed of her children, injured by merciless "brigands" and left helpless and depressed. Using the scene of inhumane robbery, Angelou exposes the unforgivable crimes committed by the western colonizers: they "took her young daughters / sold her strong sons" (Angelou, 1994, p.84).

Once they arrived in this foreign land, the ex-Africans were deprived of chances to contact their root culture and had to struggle to survive in the world where they were relegated to inferior positions. The bitterness of being treated unfairly is clearly depicted with a satirical tone in "When I Think About Myself": "The tales they tell sound like lying / they grow the fruit / But eat the rind" (Angelou, 1994, p.29). "Song for the Old Ones" deals with "the painful anguish suffered by blacks forced into submission, with guilt over accepting too much, and with protest and basic survival"(Neubauer, 1990, p.4). Similarly, Paul Dunbar (1984) reveals that the Africans survive in the hostile environment of the American plantation by "wearing the mask" (p.167). In the days of "whip and lash and stock" (Angelou, 1994, p.107), as described in this poem, to some extent, to survive means to make submission: "they say 'It's our submission / that makes the world go round"" (p.107).

Characters in the poem "Song for the Old Ones" are people passively "fulfill" the internalization and accept their "inferiority" without resistance. In contrast, the character in "Caged Bird" displays a strong desire to break through the fences of racial oppression. African Americans in this poem are compared to be "Caged Bird", while their repressed ethnic culture is symbolized by the "clipped wings." In fact, their culture and customs are more or less wiped out because these are in conflict with the dominant culture that is imposed on them. Confronted with the compulsion of Anglo-American norm and the loss of African culture, the ex-Africans have to bear the pain of losing cultural identity: "his wings are clipped and / his feet are tied" (Angelou, 1994, p.194). The "caged bird" desires to be free, it "sings / With a fearful thrill"; African Americans desire to break away from the obscure identity and realize their true self: "...the caged bird / sings of freedom" (p.194).

\subsection{Value Distortion}

Exposing the hypocrisy of the white dominating ideology is one of Angelou's tasks. In the white-centered society, African Americans cannot avoid being influenced by the dominant white cultural values that define the white as good and beautiful and the black as sinful and ugly. As Gutman (1977) once said, "African-Americans always find that they are in possession of a zero image which results from their sense of worthlessness" (p.534). And it is also this "zero image" that threatens African Americans in further realizing their self-value and fulfilling their personhood.

To reveal the deceiving alien value, Angelou displays the truth in her poem "Kin": "You fought to die, thinking / In destruction lies the seed / Of birth..." (Angelou, 1994, p.158). As in "Savior," Angelou expresses the complex feeling of the blacks who were confused by their marginal identity: "Your children, burdened with / Disbelief, blinded by a patina / of wisdom" (Angelou, 1994, p.250). In the closing part, the poet expresses her utmost satire of the distorted value of the whites': "We cry for you / Although we have lost / Your name" (p.250). In "Just Like Job", Angelou bitterly satirizes the false ideals. During the slavery period the blacks contributed remarkably to the alien land while they were subdued to the lowest living condition: "When my blanket was nothing but dew, / Rags and bones / Were all I owned" (Angelou, 1994, p.172). They desired to obtain a fair status in the country where they had sacrificed their lives: "My life give I gladly to Thee / Deep rivers ahead / High mountains above" (p.172), nevertheless, the white culture did not provide such position for them, so they were puzzled and afraid: "But fears gather round like wolves in the dark. / have You forgotten my name?" (p.172).

When the slaves were set free, they were inspired by the Constitution. However, they were never able to fulfill their aspiration. Instead, most of them had to live in the ghettos and were still confronted with poverty, racial discrimination and unemployment. The schoolyard chant "Harlem Hopscotch" reflects this truth: "Since you black, don't stick around. / Food is gone, the rent is due, / Curse and cry and then jump two" (Angelou, 1994, p.51). The inalienable rights to pursue happiness, equality and wealth that are entitled to "every American" seem to be never fulfilled in their lives. Therefore, to African Americans, to be fully integrated into the white mainstream society is nothing short of an illusion.

\section{Resurrection of the Black Self}

DuBois (1994) views the history of the American Negro is the history of "this longing to attain self-conscious 
manhood, to merge his double self into a better and truer self" (p.191). For DuBois, the discovery of self-consciousness is "a kind of awakening, the emergence of a repressed truth from the recesses of oppressive cultural systems" (Gikandi, 2005). Angelou also shows deep interest in strengthening African Americans' cultural identity by devoting herself to the recovery of the black self. Therefore, affirming and celebrating black identity play a crucial role in Angelou's works. The effort to restore the black self, as shown in Angelou's poetry, involves cultural practice of recasting black identity and redefining blackness. The source for black self-definition, Angelou believes, is the union of Black pride and African American culture. Thus, she devotes herself to educating and affirming the positive meaning of blackness.

\subsection{Celebration of Black Identity}

On arrival on the alien land, the ex-Africans lost every touch with their ancestors as well as their root culture. Their original names - real names - were one of the few links to the culture of their motherland. In some sense, their African names stood for their cultural identity, representing their collective self or their images reflected in the society. At first, the white dominators changed the ex-Africans' names for their own convenience. Gradually, the dominators imposed various insulting names upon the dominated ex-Africans so as to debase them. And the acceptance of these names symbolizes the conformation to the white dominant culture and the recognition of zero images. Indeed, the state of their names can truly reflect their images. African Americans lacking (proper) names appear in such poems as "Our Grandmothers", "Request" and "When I Think About Myself". The names given by the white oppressors in "Our Grandmothers" reveal the fact that African Americans were once reduced to animals; they were once called "nigger, nigger bitch, heifer, / mammy, property, creature, ape, baboon, / whore, hot tail, thing, it" (Angelou, 1994, p.256). Instead of accepting the names passively, characters in "Request" resist the zero images. In the poem, Angelou ironically views African Americans as a young "bastard" discarded without a status. Similar to the child depicted in the poem who suffered from a lack of legal status, African Americans feel great pain with their abnormal identity and bear their zero images. In this case, Angelou speaks out the collective quest of African Americans for positive cultural identities: "Give a legal name to beg from / for the first / time of its life" (Angelou, 1994, p. 83).

In "The Calling of Names" and "Our Grandmothers", the act of self-entitlement is completely demonstrated. In "The Calling of Names", political identity of African Americans changes with their names from "African, Colored, and Negro to Black" (Angelou, 1994, p.46). The poem shows that during the slavery period, African Americans could not be treated as a normal human being: "He went to being called a colored man / after answering to "hey, nigger"' (p.46). However, with their racial awakening, they obtain their new social status: "From colored man to Negro / With the N in caps" (p.46). This procedure is a "big step" for the liberation of African Americans, and the change in names is a change for true.

The process of renewing identity reached its peak when African Americans replaced the insulting "niggers" with the new identity "Black". During the "Black Power Movement", "Blackness" is put forward and emphasized. Adhering to Blackness in white culture is to sabotage the dominant cultural system and redefine a new one. Here, Angelou replaces the bitterness that once ran through African Americans' lives with wrath. What is reflected is a sense of power instead of a sense of frustration. This is shown in "The Calling of Names": "Now you'll get hurt / if you don't call him "Black"' (Angelou, 1994, p.46).

To heighten her people's awareness of their black identity, Angelou depicts groups of new Black people who are completely different from the stereotypical "Uncle-Toms" in her poetry. These characters demonstrate that the once debased black identity now becomes dignified, the once weak self-awareness now strengthened, and the once negative self-image now positive. Angelou produces a series of poems such as "One More Round," "Weekend Glory" and "Times-Square-Shoeshine-Composition." In these poems, Angelou portrays several working-class African Americans who willingly accept their black identity and revise the once zero images for themselves. What Angelou achieves by doing this is to bring about the spontaneous redefinition of the black individual, not as an alienated, but as a new and whole person who occupies a totally different social space.

"Weekend Glory" fatherly presents an African American woman taking pride in being black and positive about her self-image: "If they want to learn how to live life right, / they ought to study me on Saturday night"(Angelou, 1994, p.206). On weekend, those workers would "Then get spruced up / and laugh and dance" (p.206) because they are assured that they equally have the right to enjoy life just as the whites. This character is fully aware that it is her black identity that provides cultural strength as well as resourcefulness. And the cultural strength permits a reversal of domination and transforms what was once perceived by the white as inferior and weak race image.

Angelou demonstrates her deep concern by depicting African American bourgeoisie in the face of the white homogenizing culture. In order to achieve the elevation of status within the white dominant culture, some of the 
African American middle class choose to accept the white values, giving up their conventional black ideology. In "Sepia Fashion Show", Angelou portrays the typical African American bourgeoisie who are busy climbing the social ladders to achieve social advancement at the price of the African American cultural heritage that had once filled their life. In order to be involved in the white culture, they deviate from their mother culture: "The Black Bourgeois, who all say "yah" / when yeah is what they're meaning" (Angelou, 1994, p.48). As implied in the poem, their social status remains inferior to the white. And the only price for participating in the order of the white is the loss of black individuality and the adherence to social conformity. Tragically, while African American bourgeoisie in the poem strive to be absorbed into the larger ambit of the white culture, they fail to realize the fact that the white mainstream society will still exclude them instead of fully accepting them. They seem to refuse to understand that within the white-dominated society, they could not be as absolutely equal as the white bourgeoisie and participate in their social circles. Obviously, by comparing the self-denied bourgeoisie with the self-accepted working-class African Americans, Angelou extols the new blacks who take positive attitude toward their black identity, stick to black consciousness and resist the dominant ideology.

\subsection{Identification with Blackness}

Hagen (1997) states that Angelou writes about "the pride of blackness and African heritage" (p.118).Like most African American writers, Angelou plays the role of the maker of black culture. To some extent, she helps produce among African Americans the desire to reinterpret their own culture as well as reshape their self-identity. Angelou assures that the black writers are in positions to inform, to form and to influence.

The metaphor of "black" informing her works successfully subverts Anglo-American old cultural ideology. The dominant aesthetic based on the white ideology defined beauty and nobleness as related only with white while being black as a symbol of ugliness and humbleness. Nonetheless, in Angelou's poetry, the old value is challenged and reverted. The new value exemplified in Angelou's poetry is to be black is no disgrace but an honor because black is beautiful.

"Ain't That Bad?" is a typical representation of stressing "Black is Beautiful"; "bad" is the black slang for "good". Hagen (1997) explains that the poet praises black culture, mores, customs, and leaders in this poem (p.127). Black, in the poem, is symbolized as the source of new life. Coupled with the earth and night, "black" implies the enormous creative power. The intentional coupling of black and night is also a resistant act to demystify the black myth. In early white literature, just as nights, the black to the white are mysterious, wild, dangerous and irrational. When referring to African Americans, night contains the negative meaning by the white. However, "black night" in this poem bears positive meanings of regeneration and immense power of the black. Black is also respected as the mother of all nations: "Black as the earth which has given birth / To nations, and when all else is gone will abide" (Angelou, 1994, p.165).

Within the context of the white culture, the white images are planted at the core of people's life, the most obvious example being that of the Church, where God is white. So in her religious poem "Thank You, Lord", Angelou deliberately smashes the white idol of the summit of authority, changes the mythical figure of the Lord deeply entrenched in white culture. In this poem, the stereotyped Jesus image for blacks turns out to be a "brown-skinned" one close to African Americans: "Brown-skinned / Neat Afro / Full lips" (Angelou, 1994, p.175).The black heroes are eulogized: "A Malcolm, / Martin, / Du Bois" (p.175).

The strength and courage generated by the black are also exemplified in "Still I Rise". In the poem, the narrator compares himself to a black ocean which is the source of endless energy and courage empowering the dominated people to survive, triumph over oppression and to achieve positive self-identity: "I'm a black ocean, leaping and wide, / Welling and swelling I bear in the tide" (Angelou, 1994, p164).

As a metaphor of immense power, black also weaves itself into the poem "A Georgia Song". The poem is inspired by the old stereotype of the black slave as a "Sambo". In the first two stanzas, the poet leads us to the past which was filled with "notes of / Sorrow songs" (Angelou, 1994, p.187). The Southern land is "blood-red" which suggests an underlying meaning of the "ancient wrongs" committed to the blacks. The white imposed cultural hegemony on the black: the moon was "whitened". The cultural dominance irritated African Americans and the merciless behavior was severely condemned. Besides expressing great sorrow and hatred, Angelou calls on her people to courageously react to the racists: "We need a wind to strike / Sharply..."(p.188). Wind here obviously suggests the force to fight against inequality. The poet passionately appeals to the cultural subversion: "Dare us new dream, ..." (p.188). The indomitable will and courage of her people is reflected by requesting a "new moon" which is a sharp contrast with the "whitened moon" previously related.

A final metaphor for black pride is African cultural heritage. In the 1960s, she visited Africa and started a journey of quest for her past. Not surprisingly, her sojourn in Africa helped her understand herself both as an 
African and as an American. In Africa she had found the sense of pride of her own culture. She was aware of her native culture heritage which had been profoundly retained for centuries by the African descendants. In the new era, Africa bears a new meaning to them; it becomes their spiritual home and cultural root. In some ways, African Americans are cultural exiles and their relationship to the African cultural heritage has been stretched thin over distance and generations. African culture is a bridge between them and their spirits helping connect the exiles with the ancestors. Therefore, identifying with their mother culture helps African Americans discover their past and redefine themselves. And preserving the black cultural heritage in the face of homogenizing function of the white-dominating society is an effective way of reversing cultural hegemony and reviving their own culture.

Acutely conscious of the strength of her culture, Angelou eulogizes the beauty of Africa-her mother culture by utilizing various images closely related with African culture.

"Ocean" frequently appears in her poems standing for the splendid ancient African culture. In "Still I Rise", she says: "I'm a black ocean, leaping and wide, / Welling and swelling I bear in the tide"(Angelou, 1994, p.164). In addition, in "Just Like Job", the image of river appears again: "My life... / Deep rivers ahead / High mountains above" (Angelou, 1994, p.172). The "rivers" relate to the glorious African civilization. Relative images are employed in her poems like "beach" and "boat".

Sunrise is another image of the spiritual hometown of African Americans. In "Where We Belong, A Duet", Angelou demonstrates great pride by identifying with the culture source-Africa: "Then you rose into my life / Like a promised sunrise" (Angelou, 1994, p.128). The sunrise, which is the guidance of the blacks, is "Brightening my days with the light" (p.128). Only by embracing African culture could African Americans be strong enough to resist cultural assimilation in the white environment: "I've never been so strong, / Now I'm where I belong" (p.128).

\section{Conclusion}

Realizing the devastating impact the dominant culture exerts on the development of marginal groups, Angelou devotes herself to advocating a healthier cultural context. In her poetry, she retreats back to the oppressive memories that generations of African Americans have ever had. For African Americans, maintaining their African culture enables them to survive in an alien world. To recover her people's self-consciousness and restore their identity, Angelou makes great efforts to redefine blackness. By assimilating themselves with their ancestor's culture, they are able to renew their self and truly know themselves. In doing so, she keeps alive ethnic culture and leads African Americans out of the margin. Therefore, Maya Angelou is a cultural poet who fulfills the task of transmitting cultures.

\section{Acknowledgements}

I would like to take this chance to express my heartfelt gratitude to Dr. John K. Marah, professor of African \& African-American Studies Department, College at Brockport, State University of New York. During my research at the college funded by China Scholarship Council, Dr. Marahhas offered me his insightful commentary and intellectual support.

\section{References}

Angelou, M. (1994). The Complete Collected Poems of Maya Angelou. New York: Random House, Inc.

Awkward, M. (1995). Negotiating Difference: Race, Gender, and the Politics of Positionality. University of Chicago Press.

Davis, A. Y. (1983). Women, Race, \& Class (1st ed.). New York: Random House, Inc.

DeGout, Y. Y. (2009). The Poetry of Maya Angelou: Liberation Ideology and Technique. In H. Bloom (Ed.), Bloom's Modern Critical Views—Maya Angelou (pp. 110-125). New York: Infobase Publishing.

DuBois, W. E. B. (1994). The Souls of Black Folk. New York, NJ: Gramercy Books.

Dunbar \& Paul, L. (1984). Lyrics of Lowly Life: The Poetry of Paul Lawrence Dunbar. New York: Citadel Press.

Evans, M. (1984). Black Women Writers (1950-1980): A Critical Evaluation. Anchor.

Gikandi, S. (2005). W. E. B. DuBois and the Identity of Africa. Ann Arbor. MI: MPublishing, University of Michigan Library. Retetreved from http://quod.lib.umich.edu/g/gefame/4761563.0002.101/--w-e-b-dubois-and-the-identity-of-africa?rgn=main; view=fulltext

Guerin, W. L. et al. (Eds.). (2004). A Handbook of Critical Approaches to Literature. Beijing: Foreign Language Teaching and Research Press. 
Gutman, H. G. (1977). The Black Family in Slave and Freedom. New York: Vintage Books/Random House.

Hagen, L. B. (Ed.). (1997). Heart of a Woman, Mind of a Writer, and Soul of a Poet: A Critical Analysis of the Writings of Maya Angelou. Lanham: University Press of America, Inc.

Hooks, B. (2000). Feminist Theory: From Margin to Center (2nd ed., pp. 86-92). Boston: South End Press.

Lupton, M. J. (1998). Maya Angelou: A Critical Companion. Westport, Connecticut: Greenwood Press.

Neubauer, C. E. (1990). Maya Angelou: Self and a Song of Freedom in the Southern Tradition. In T. B. Inge (Ed.), Southern Women Writers: The New Generation. Tuscaloosa, Alabama: The University of Alabama Press. Retrieved from

http://blackbirdlibrary.pbworks.com/w/file/fetch/64614716/MayaAngelouShakerCriticism Excerpt.pdf

Washington, E. B. (2002). A Song Flung Up to Heaven. Black Issues Book Review, 4(2).

Washington, M. H. (1980). Midnight Birds: Stories by Contemporary Black Women Writers. Anchor Books.

\section{Copyrights}

Copyright for this articleis retained by the author(s), with first publication rights granted to the journal.

This is an open-access article distributed under the terms and conditions of the CreativeCommons Attribution license (http://creativecommons.org/licenses/by/3.0/). 